anales de psicología, 2018, vol. 34, $\mathrm{n}^{\circ} 1$ (january), 117-122 http://dx.doi.org/10.6018/analesps.34.1.267311
(C) Copyright 2018: Editum. Servicio de Publicaciones de la Universidad de Murcia. Murcia (Spain) ISSN print edition: 0212-9728. ISSN web edition (http://revistas.um.es/analesps): 1695-2294

\title{
Intergroup trust and anxiety: The two sides of stigma towards people with Down syndrome
}

\author{
Naira Delgado*, Eva Ariño, Verónica Betancor, and Armando Rodríguez-Pérez
}

Universidad de La Laguna (Spain).

\begin{abstract}
Título: Confianza y ansiedad intergrupal: los dos lados del estigma hacia las personas con síndrome de Down

Resumen: Las personas con síndrome de Down sufren un tipo de estigmatización ambivalente, que combina estereotipos, reacciones emocionales y actitudes positivas y negativas. El objetivo de este estudio es analizar la relación que existe entre las actitudes ambivalentes hacia las personas con síndrome de Down, y los niveles de confianza y ansiedad intergrupal que se mantienen hacia ellas. Un total de 144 estudiantes universitarios respondieron a un cuestionario sobre la percepción social que mantienen hacia este colectivo, e indicaron en qué medida anticipan una interacción con personas con síndrome de Down basada en la confianza o en ansiedad intergrupal. Los resultados indican que se producen respuestas ambivalentes hacia las personas con síndrome de Down. Además, mientras que la confianza intergrupal está relacionada con altos niveles de admiración y competencia, la ansiedad intergrupal está relacionada con niveles altos de aversión, compasión y baja admiración. Se discuten las implicaciones de estos resultados alcanzados de cara a mejorar la percepción social de las personas con síndrome de Down, así como el complejo papel que juega la compasión en la valoración de grupos estigmatizados.

Palabras clave: Síndrome de Down; estigmatización; ansiedad intergrupal; compasión
\end{abstract}

\section{Introduction}

The open expression of prejudice is influenced by social norms that invite a show of rejection towards certain groups, while displays of prejudice towards others is vehemently censured (Jason, Greiner, Naylor, Johnson \& van Egeren, 1991; Rodríguez-Pérez, Betancor \& Delgado, 2009) For example, at present, we can show prejudice towards politicians, bankers and delinquents, but not towards people with disabilities or immigrants. This fact is not about a real reduction of prejudice towards these groups, but rather the restriction on the freedom to openly show such prejudice.

In this study, we analyse attitudes towards a group which is protected from the open expression of prejudice by the social norm: people with Down syndrome. Specifically, the main goal of this study is to analyse the relationship between attitudes towards people with Down syndrome and the levels of intergroup trust and anxiety felt towards them.

\section{The stigma of people with Down syndrome}

Society's perception of people with intellectual disabilities has undergone considerable change, particularly in the last 40 years. Until the 1980s, disparaging and pejorative terms were habitually used to refer to intellectual disability. Everyday

* Correspondence address [Dirección para correspondencia]: Naira Delgado. Departamento de Psicología Cognitiva, Social y Organizacional, Universidad de La Laguna, 38071, Tenerife (Spain).

E-mail: ndelgado@ull.es
Abstract: People with Down syndrome experience a type of ambivalent stigmatisation, which combines stereotypes, emotional reactions, and both positive and negative attitudes. The aim of this study is to analyse the relationship between ambivalent attitudes towards people with Down syndrome, and the levels of intergroup trust and anxiety felt towards them. A total of 144 university students completed a questionnaire on their social perception of people with Down syndrome, indicating the extent to which they anticipate an interaction with this group based on trust or anxiety. The results show that responses to people with Down syndrome are ambivalent. Moreover, while intergroup trust is associated with high levels of admiration and competence, intergroup anxiety is associated with high levels of aversion, compassion and low admiration. We discuss the implications of these results, taking into account how to enhance the social perception of people with Down syndrome, as well as the complex role of compassion in the assessment of stigmatised groups.

Keywords: Down syndrome; stigmatisation; intergroup anxiety; compassion.

and clinical use included idiot, imbecile, cretin, subnormal, mental retard, mongol, moron, deviant, incapable and maladjusted (Edgerton, 1980; Taylor, 2013). An intellectual disability by definition implied a negative perception of the person, a depersonalisation and reduction of their humanity (Edgerton, 1980; Goffman, 1970).

Today, in order to understand how stigmatisation of people with intellectual disabilities occurs, it is necessary to take into account a new conceptualisation that includes the ambivalence of the stigma towards this group. Specifically, Werner (2015) presents a model in which the stereotypes, prejudice and discrimination towards this group display ambivalence. Thus, stereotypes include positive thoughts and acceptance, along with negative thoughts linked to low capacity and aggressiveness. Similarly, prejudice also includes elements of rejection as well as compassion. Finally, discrimination towards these people combines positive aspects, which are linked to helpful behaviour, with rejection behaviour and restricted opportunities.

Despite scant research on stigma towards people with Down syndrome, the results of several studies coincide with Werner's (2015) stigmatisation model. People with Down syndrome are perceived through stereotypes of considerable warmth, with friendly, affectionate, happy and sociable characteristics (Gilmore, Campbell \& Cuskelly, 2003) Yet, at the same time, they are stereotyped as incompetent and assigned characteristics such as problematic and aggressive, irrational, retarded and being a social nuisance (Heinemann, 1990; Pary, 2004). 
Moreover, as considered in Werner's (2015) stigmatisation model for people with intellectual disabilities, several studies have found that there is a collective attitude of tolerance and inclusion, which is reflected in a favourable disposition towards integration into education and the labour market (Guralnick, Connor \& Hammond, 1995). However, paternalistic attitudes towards this group still persist and occasionally result in overprotection that can be offensive. Indeed, family members often show exaggerated concern, which can result in a loss of autonomy for people with trisomy 21 , altering the way in which they face certain life events, such as marriage or independence from the parental home (Molina \& Illán, 2011; Price-Williams, 1989).

Negative attitudes are also reflected in a study done in the United States by Pace, Shin and Rasmussen (2010), in which they analysed the attitudes of a sample of adults and a sample of teenagers towards the integration of people with Down syndrome into education. The authors found that $25 \%$ of the adults disagreed with the educational inclusion of people with trisomy 21 (alleging, for example, that they would distract the attention of the other students). Furthermore, a third of the teenagers claimed that they would not be prepared to work on a class project or spend time after school with a student with trisomy 21.

To date, there has been little research into the consequences of this form of stigmatisation in intergroup relations. For this reason, we speculate whether the ambivalent perception of this type of group influences the way in which we behave towards them.

\section{Intergroup anxiety towards socially protected groups}

The theory of intergroup anxiety was developed by Stephan and Stephan (1985) to describe feelings of discomfort or anxiety when interacting with members of other social groups. These authors claim that these emotions can appear when a person is either interacting or anticipating an interaction with a member of the outgroup, that is, despite the absence of real contact.

Intergroup anxiety has been shown to be a very important affective variable for predicting prejudice (Riek, Mania \& Gaertner, 2006; Stephan \& Stephan, 1985). The expectations and negative sentiments that characterise intergroup anxiety generate a predisposition to respond negatively to members of the outgroup, whether in a non-verbal and subtle manner or openly (Stephan, 2014).

According to Stephan (2014), there are four basic categories of antecedents of intergroup anxiety: (1) personality traits and other personal characteristics, (2) attitudes and other related cognitions, (3) personal experiences, and (4) situational factors.

One of the most studied antecedents of intergroup anxiety is the role of attitudes and beliefs about the group, which is the focus of the present research. Specifically, it has been found that the more negative the stereotype and attitudes towards a group, the greater the likelihood of the appearance of intense manifestations of intergroup anxiety (Aberson \& Gaffney, 2009; Van Zomeren, Fischer \& Spears, 2007). Moreover, anxiety increases if the members of the outgroup are believed to be potentially dangerous and to represent a threat to oneself or to members of the ingroup (RenfroFernandez \& Stephan, 2009).

That said, beliefs about outgroups do not influence intergroup anxiety alone. Group norms also influence the emotions that members should feel in their relations with outgroups. If the social norm defends contact with a specific group, then the interaction with a member of that outgroup can be seen as normal behaviour or as a moral obligation (Stephan, 2014).

However, not always the emotions and beliefs displayed towards an outgroup are clearly negative. In the case of people with Down syndrome, in which ambivalent attitudes such as discomfort and feelings of threat coexist with paternalism and compassion, it is difficult to determine the role played by different emotions in intergroup anxiety, and whether they have attenuating or enhancing effects. The lack of research in this field, especially with compassion, justifies the need to explore whether individuals manifest intergroup anxiety when imagine an interaction with people with Down syndrome and to discover which factors are related with this collective emotional response. Therefore, the purpose of this study is to analyse the extent to which attitudes towards people with Down syndrome are related with intergroup trust and anxiety displayed to that social group.

\section{Methods}

\section{Participants}

A total of 144 social work undergraduates at the University of La Laguna (120 women and 24 men) participated voluntarily in this study (it was an incidental sample). The mean age was $19.68(S D=3.03)$. All of them were residents in Tenerife (Canary Islands). The anonymity of the participants was guaranteed. The students were awarded research credits for participating.

\section{Materials and tools}

\section{Stereotypes}

In order to measure the stereotyping of people with Down syndrome, we used the translation and adaptation of the stereotype scale created by Navas, López-Rodríguez \& Cuadrado (2013), based on the measurement by Fiske, Cuddy, Glick \& Xu (2002), composed of 12 items, half of which were associated with sociability dimensions: friendly, wellintentioned, trustworthy, warm, good-natured, sincere, and the other half with competence: competent, intelligent, confident, capable, efficient and skilful (competence). Participants were asked to indicate how they thought Spanish society perceived people with 
Down syndrome, according to a 5 -point response scale $(1=$ Not at all; $5=$ Extremely). Cronbach's alpha coefficient was .81 for Sociability and .85 for Competence. The dimensions were created from the mean of their corresponding items. High scores indicate a higher presence of this dimension in the stereotype.

\section{Emotional reactions}

This test was composed of 20 items taken from Glick and Fiske (2001), used in Spanish in Sirlopú et al.'s (2012) study. Participants indicated the extent to which Spanish society felt these emotions towards people with Down syndrome. Scores were obtained on a 7-point Likert scale, ranging from 1 (Not at all) to 7 (Extremely). The test comprises three dimensions: Admiration (admiration, respect, warmth, pride, inspiration; $\alpha=.77$ ), Compassion (compassion, sympathy, pity; $a=.67$ ) and Aversion (indignation, resentment, hate, jealousy, envy, contempt, shame, humiliation, disgust, anxiety, anger, frustration; $a=.89$ ). For each dimension, high scores indicate a high level of the dimension.

\section{Intergroup trust and anxiety}

In order to measure intergroup trust and anxiety, we employed a short version of Stephan and Stephan's (1985) test, used in Spanish in Sirlopú et al.'s (2008) studies. Students were asked "To what extent does Spanish society feel these emotions on interacting with a person with Down syndrome?". Each of the eight items was assessed on a 7-point Likert scale, ranging from 1 (Not at all) to 7 (Extremely). Internal consistency for the four items of intergroup trust (Tolerance, Relaxation, Trust and Safety) and the four items of intergroup anxiety (Nervousness, Tension, Discomfort and Threat) was $a=.78$ and $a=.81$, respectively.
The questionnaire included other questions, extracted by Sirlopú et al. (2008). Due to the lack of internal consistency obtained ( $a=.50$ in two dimensions), as well as the overlapping with other measures, we decided to exclude them from the analyses.

\section{Procedure}

Participants completed the questionnaire online using the Survey Monkey tool. Researchers provided participants a link that they have to use to have access to the questionnaire. The task took less than 15 minutes for each participant. Following Ato, López \& Benavente (2013), we present a selective study within observational methodology.

\section{Statistical analyses}

A descriptive analysis of all the dimensions included in the questionnaire was carried out. In order to determine differences in scores of stereotypes, emotional reactions and intergroup trust/anxiety, t-test comparisons were established between the following dimensions: competence and sociability; compassion, admiration and aversion; intergroup trust and intergroup anxiety. To analyse the relationship between stereotypes / emotional reactions, and intergroup trust and anxiety, two regression models were applied, with Stepwise Method. All the analyses were conducted with SPSS v19.

\section{Results}

The mean scores assigned by participants to people with Down syndrome in all the dimensions included in this study, as well as correlation between them, are shown in Table 1 .

Table 1. Means and correlations among study variables.

\begin{tabular}{|c|c|c|c|c|c|c|c|c|}
\hline & Mean & $S D$ & 1 & 2 & 3 & 4 & 5 & 6 \\
\hline Sociability & 3.80 & 0.67 & & & & & & \\
\hline Competence & 2.33 & 0.73 & $.491 * *$ & & & & & \\
\hline Admiration & 2.36 & 0.69 & $.489 * *$ & $.504^{* *}$ & & & & \\
\hline Compassion & 3.89 & 0.59 & -.159 & $-.305^{* *}$ & -.180 & & & \\
\hline Aversion & 2.02 & 0.62 & $-.375^{* *}$ & $-.347 * *$ & $-.413 * *$ & $.284^{* *}$ & & \\
\hline Intergroup Trust & 4.12 & 1.22 & $.378^{* *}$ & $.440 * *$ & $.554 * *$ & $-.193^{*}$ & $-.319 * *$ & \\
\hline Intergroup Anxiety & 4.64 & 1.34 & $-.395^{* *}$ & $-.411 * *$ & $-.477 * *$ &, $472^{* *}$ & $.670^{* *}$ & $-.464 * *$ \\
\hline
\end{tabular}

The pattern of correlations showed interesting results. Competence and sociability were highly related $(r=.491, p<.01)$. Compassion was inversely related with competence $(r=$ $.305, p<.01)$, and directly related with aversion $(r=.284, p$ $<.01)$. There was a high correlation between intergroup trust and admiration $(r=.554, p<.01)$, and a clear and direct association between intergroup anxiety and compassion $(r=$ $.472, p<.01)$.

As shown in Table 2, stereotypical representation is more determined by sociability $(M=3.80 ; S D=0.67)$ than by competence $(M=2.33 ; S D=0.73 ; t(142)=21.75 ; p<.001)$. For emotional reactions to persons with Down syndrome, the results reveal more compassion $(M=4.64 ; S D=1.34)$ than admiration $(M=4.12 ; \quad S D=1.22 ; \quad t(141)=2.80$; $p=.004)$, more compassion than aversion $(M=2.48$; $S D=105 ; t(141)=15.77 ; p<.001)$ and more admiration than aversion $(t(141)=9.09 ; p<.001)$. Finally, intergroup anxiety ratings were not significantly different from those obtained for intergroup trust $(p=.28)$. 
Table 2. Results of the t-test comparisons in each block of dimensions.

\begin{tabular}{lll}
\hline & $t(\mathrm{df})$ & Sign. \\
\hline Sociability - Competence & 21.75 & $<.01$ \\
Admiration - Compassion & 2.80 & $<.01$ \\
Compassion - Aversion & 15.77 & $<.01$ \\
Aversion - Admiration & 9.09 & $<.01$ \\
Intergroup Trust - Intergroup Anxiety & 1.08 & .280 \\
\hline
\end{tabular}

To explore the extent to which stereotypes and emotional reactions are associated with intergroup trust and anxiety, we carried out a multiple linear regression analysis, following the Stepwise Method, taking Intergroup trust (model 1) and Intergroup anxiety (model 2 ) as a criterion variable.

Table 3. Results of the linear regression analysis relating to intergroup trust and anxiety.

Model 1. Intergroup trust.

\begin{tabular}{|c|c|c|c|c|c|c|}
\hline Model & $\mathrm{R}^{2}$ corrected & $F$ & Sign. & $\beta$ & $t$ & $p$ \\
\hline $\begin{array}{l}\text { Admiration } \\
\text { Competence }\end{array}$ & 0.33 & 28.32 & $<0.001$ & $\begin{array}{l}0.45 \\
0.21\end{array}$ & $\begin{array}{l}4.96 \\
2.39\end{array}$ & $\begin{array}{c}<.001 \\
.018\end{array}$ \\
\hline
\end{tabular}

Model 2. Intergroup anxiety.

\begin{tabular}{|c|c|c|c|c|c|c|}
\hline Model & $\mathrm{R}^{2}$ corrected & $\mathrm{F}$ & Sign. & $\beta$ & $t$ & $p$ \\
\hline Aversion & & & & 0.50 & 7.02 & $<.001$ \\
\hline Compassion & 0.56 & 48.99 & $<0.001$ & 0.29 & 4.48 & $<.001$ \\
\hline Admiration & & & & -0.22 & -3.17 & .002 \\
\hline
\end{tabular}

Table 3 shows the results of the predictive model associated with Intergroup trust and composed of the variables Admiration and Competence $\left(F_{(3,111)}=28.32, p<.001\right)$, which explained $33 \%$ of variance. Specifically, for each standard increment unit in the dimension Admiration, Intergroup trust increased by .45 units, and for each standard increment unit in the dimension Competence, Intergroup trust increased by .21 units.

Table 2 also gives the percentage of variance explained in the regression analysis relating to the variable Intergroup anxiety as $56 \%$; the predictive model was composed of the variables Aversion, Compassion and Admiration $\left(F_{(3,111)}=24.66, p<.001\right)$. Specifically, higher levels of aversion $(\beta=.48)$, together with higher levels of compassion $(\beta=.29)$, and lower levels of admiration $(\beta=-.18)$, anticipated higher levels of intergroup anxiety. When the interaction between Compassion and Aversion was included in the model, the effect was not statistically significant $(\beta=-.306 ; p$ $>.05)$.

\section{Discussion}

The goal of this study was to analyse the relationship between stereotypes, emotions associated with people with Down syndrome and intergroup trust and anxiety towards this group.

The results indicate that compassion is the most intense emotional reaction aroused by people with Down syndrome. This outcome confirms Fiske et al.'s (2002) predictions that link this emotion with paternalistic prejudice and the stereotype of low competence and high sociability. In our sample, the emotional experience of compassion correlates with aversive reactions, a result that concurs with previous findings, which reveal that primary school pupils with high levels of compassion towards people with Down syndrome also experience high levels of aversion (Sirlopú et al., 2012).

Recent empirical studies have demonstrated that compassion is an emotion associated with caring for another who is perceived as vulnerable and shows signs of suffering (Goetz, Keltner \& Simon-Thomas, 2010; Zahn-Waxler, Radke-Yarrow, Wagner \& Chapman, 1992). However, little is known about the way in which compassion influences social behaviour and judgement. In this sense, studying the relationship between compassion and intergroup anxiety is innovative and may be linked to the evaluation of social groups towards which there is a social norm of protection. Previous research in the field of intergroup anxiety has barely explored the relation between emotions towards outgroups and intergroup anxiety (Stephan, 2014), and the few studies that have been undertaken pinpoint the direct relation with emotions such as fear (Van Zomeren et al., 2007), anger (Van Zomeren et al., 2007), or negative emotions in general (Binder et al., 2009). Therefore, the results we present in this paper call for further exploration of the role played by intergroup anxiety and why, unlike empathy, which is an effective response in the progress of intergroup relations, compassion is more linked to paternalistic prejudice and negative behaviours, despite being a moral and socially valued sentiment (Dovidio, Johnson, Gaertner, Pearson, Saguy \& AshburnNardo, 2010; Fiske et al., 2002).

Furthermore, this study has found that intergroup anxiety increases in the face of high levels of compassion and aversion, and low levels of admiration. In other words, feeling compassion for people with Down syndrome is associated with more anticipated difficulties in social interaction, since it arouses anxiety responses towards them. Future research is necessary to explore the mechanisms behind the relationship between compassion and intergroup anxiety. One possible explanation is related with the role of inequality behind feelings of compassion, or discomfort that could appear in parallel to compassion. Another possibility is that compassion could spread feelings of discomfort about the situation, and this discomfort could be necessary to activate intergroup anxiety.

The results obtained have important implications with regard to designing interventions aimed at reducing prejudice and discrimination against people with Down syndrome. Such interventions should pay special attention to the affective reactions associated with compassion, less subject to social censure than emotions like aversion, but with equally negative consequences for possible satisfactory interactions with members of this group. To reduce the intergroup anxiety caused by the anticipation of interaction with people with Down syndrome, it is therefore necessary to trigger a change in stereotyping and to reduce compassionate reactions in favour of reactions of admiration for the successes and capacities of these people. 
This research had some limitations that should be taken into consideration. Firstly, gender differences in social perception towards people with Down syndrome couldn't be analysed, since the sample was composed basically for women. Secondly, the design of the study doesn't allow obtaining information about causal relationships between dimensions. Future researches should consider variables such personal experiences or contact with members of the target group in order to explore their role. Another limitation is related with the self-report measures on which it is based; it would be interesting to enhance this type of response with neuroimaging techniques to enable further exploration of the diverse emotional reactions in intergroup anxiety. Moreover, it is necessary to use alternative scales to measure attitudes, especially in the case of paternalistic attitudes towards people with Down syndrome. Finally, it would be interesting to explore

\section{References}

Aberson, C.L. \& Gaffney A.M. (2009). An integrated threat model of explicit and implicit attitudes. European Journal of Social Psychology, 39, 808830 .

Ato, M., López-García, J.J., \& Benavente, A. (2013). A classification system for research designs in psychology. Anales de Psicología, 29 (3), 10381059.

Binder J., Zagefka H., Brown R., Funke F., Kessler T., Mummendey A., Maquil A., Demoulin S. \& Leyens J. P. (2009). Does contact reduce prejudice or does prejudice reduce contact? A longitudinal test of the contact hypothesis among minority groups in three European countries. Journal of Personality and Social Psychology, 96, 843-856.

Dovidio J.F., Johnson J.D., Gaertner S.L., Pearson A. R., Saguy T. \& Ashburn-Nardo L. (2010). Empathy and intergroup relations. In M. Mikulincer \& P. R. Shaver (Eds.). Prosocial motives, emotions and behavior: The better angels of our nature (pp. 393-408). Washington,DC : American Psychological Association.

Edgerton, R. (1980). The study of deviance: marginal man or everyman? En G.D. Spindler (Ed.), The making of psychological anthropology (pp. 444476). Berkeley: University of California Press.

Fiske, S. T., Cuddy, A. J. C., Glick, P. \& Xu, J. (2002). A model of (often mixed) stereotype content: Competence and warmth respectively follow from perceived status and competition. Journal of Personality and Social Psychology, 82, 878-902.

Gilmore, L., Campbell, J. \& Cuskelly, M. (2003). Developmental expectations, personality stereotypes, and attitudes towards inclusive education: Community and teacher views of Down syndrome. International Journal of Disability, Development, and Education, 50, 65-76.

Glick, P. \& Fiske, S. T. (2001). Ambivalent stereotypes as legitimizing ideologies: Differentiating paternalistic and envious prejudice. In J. T. Jost \& B.Major (Eds.), The psychology of legitimacy: Ideology justice, and intergroup relations (pp. 278-306). New York: Cambridge University Press.

Goetz, J. L., Keltner, D., \& Simon-Thomas, E. (2010). Compassion: An evolutionary analysis and empirical review. Psychological Bulletin, 136, 351-374.

Goffman, E. (1970). Estigma. La identidad deteriorada. Buenos Aires: Amorrortu.

Guralnick, M. J., Connor, R. \& Hammond, M. (1995). Parent perspectives of peer relations and friendships in integrated and specialized programs. American journal of mental retardation, 99, 457-476.

Heinemann, W. (1990). Meeting the handicapped: A case of affectivecognitive inconsistency. European Review of Social Psychology, 1, 323-338.

Jason, L. A., Greiner, B. J., Naylor, K., Johnson, S. P. \& Van Egeren, L. (1991). A large-scale, short-term, media-based weight loss program. American Journal of Health Promotion, 5, 432-437. the role of compassion in intergroup anxiety in real (not imagined) interactions.

In short, the results found support the idea that, although hostile reactions towards people with Down syndrome have decreased considerably in recent decades and are socially condemned, egalitarian attitudes towards this group are far from stable. The persistence of feelings of compassion and aversion towards people with Down syndrome, as well as the high levels of intergroup anxiety towards them, cause uncomfortable and unsatisfactory interactions, which may strengthen and confirm the stereotypes, beliefs and attitudes that were held prior to the interaction.

Acknowledgments.- This research was supported by two research projects, PSI2009-09777 and PSI2012-34227 — Office of Scientific and Technical Research (DGICYT from the acronym in Spanish).

Molina, J. \& Illán, N. (2011). El proceso de integración efectiva de los alumnos con síndrome de Down en Educación Infantil: variables influyentes en dicho proceso. Revista Española de Pedagogía, 248, 5-22.

Navas, M., López-Rodríguez, L. \& Cuadrado, I. (2013). Mantenimiento y adaptación cultural de diferentes grupos inmigrantes: variables predictoras. Anales de Psicología, 29 (1), 207-216.

Pace, J., Shin, M. \& Rasmussen, S. A. (2010). Understanding attitudes toward people with Down syndrome. American Journal of Medical Genetics Part A, 152 A (9), 2185-2192.

Pary, R. J. (2004). Behavioral and psychiatric disorders in children and adolescents with Down syndrome. Mental Health Aspects of Developmental Disabilities, 7, 69-76.

Price-Williams, D. R. (1989). Communication in therapy with emotionally disturbed mentally retarded individuals. In M. Beveridge, G. ContiRamsden, \& I. Leudar (Eds.), Language and communication in mentally handicapped people (pp. 254-273). London: Chapman and Hall.

Renfro-Fernandez, C. L. \& Stephan, W. G. (2009), Intergroup Anxiety. En J. Levine and M. Hogg (Eds.), Encyclopedia of Group Processes and Intergroup Relations. (pp.465-468). Thousand Oaks, CA: Sage.

Riek, B. M., Mania, E. W. \& Gaertner, S. L. (2006). Intergroup threat and outgroup attitudes: A meta-analytic review. Personality and Social Psychology Bulletin, 10 (4), 336-353.

Rodríguez-Pérez, A., Betancor, V. \& Delgado, N. (2009). La norma social sobre la expresión del prejuicio explícito hacia diferentes grupos sociales. Revista de Psicología Social, 24, 17- 27.

Sirlopú, D., González, R., Bohner, G., Siebler, F., Millar, A., Ordóñez, G., Torres, D. \& De Tezanos-Pinto, P. (2012). Actitudes implícitas y explícitas hacia personas con síndrome de Down: un estudio en colegios con y sin programas de integración de Chile. [Implicit and explicit attitudes toward people with Down syndrome: A study in schools with and without integration programmes in Chile.]. Revista de Psicología Social, 27, 199-210.

Sirlopú, D., González, R., Bohner, G., Siebler, F., Ordóñez, G., Millar, A. Torres, D. \& De Tezanos-Pinto, P. (2008). Promoting positive attitudes toward people with Down Syndrome: The benefit of school inclusion programs. Journal of Applied Social Psychology, 38, 2710-2736.

Stephan, W. G., \& Stephan, C. W. (1985). Intergroup Anxiety. Journal of Social Issues, 41 (3), 157-175.

Stephan, W. G. (2014). Intergroup anxiety: Theory, research, and practice. Personality and Social Psychology Review, 18 (3), 239-255.

Taylor, D. (2013). Stigma and prejudice in the language of sickness. Epilepsy y Behavior, 27, 204-205.

Van Zomeren, M., Fischer, A. H., \& Spears, R. (2007). Testing the limits of tolerance: How intergroup anxiety amplifies negative and offensive re- 
sponses to out-group-initiated contact. Personality and Social Psychology Bulletin, 33, 1686-1699.

Werner, S. (2015). Public stigma in intelectual disability: Do direct versus indirect questions make a difference? Journal of Intellectual Disability Research, 59 (10), 958-969.
Zahn-Waxler, C., Radke-Yarrow, M., Wagner, E., \& Chapman, M. (1992). Development of concern for others. Developmental Psychology, 28 (1), 126-136.

(Article received: 11-09-2016; revised: 13-03-2017; accepted: 04-04-2017) 